\title{
Choosing teams
}

Citation for published version (APA):

Wagner, L. (2018). Choosing teams: Imagining futures of diaspora through the 2018 World Cup. African Diaspora, 11(1-2), 179-192. https://doi.org/10.1163/18725465-01101003

\section{Document status and date:}

Published: 01/01/2018

DOI:

10.1163/18725465-01101003

Document Version:

Publisher's PDF, also known as Version of record

\section{Document license:}

Taverne

\section{Please check the document version of this publication:}

- A submitted manuscript is the version of the article upon submission and before peer-review. There can be important differences between the submitted version and the official published version of record.

People interested in the research are advised to contact the author for the final version of the publication, or visit the DOI to the publisher's website.

- The final author version and the galley proof are versions of the publication after peer review.

- The final published version features the final layout of the paper including the volume, issue and page numbers.

Link to publication

\footnotetext{
General rights rights.

- You may freely distribute the URL identifying the publication in the public portal. please follow below link for the End User Agreement:

www.umlib.nl/taverne-license

Take down policy

If you believe that this document breaches copyright please contact us at:

repository@maastrichtuniversity.nl

providing details and we will investigate your claim.
}

Copyright and moral rights for the publications made accessible in the public portal are retained by the authors and/or other copyright owners and it is a condition of accessing publications that users recognise and abide by the legal requirements associated with these

- Users may download and print one copy of any publication from the public portal for the purpose of private study or research.

- You may not further distribute the material or use it for any profit-making activity or commercial gain

If the publication is distributed under the terms of Article $25 \mathrm{fa}$ of the Dutch Copyright Act, indicated by the "Taverne" license above, 


\title{
Choosing Teams
}

\section{Imagining Futures of Diaspora through the 2018 World Cup}

\author{
Lauren B. Wagner \\ Maastricht University \\ l.wagner@maastrichtuniversity.nl
}

\begin{abstract}
The future of diaspora goes together with the future of diversity, and the different ways in which states and nations can reconfigure how their mobile, multifaceted members are accepted as belonging. The 2018 FIFA World Cup, like many international sporting events, crystallised some of debates about citizenship and belonging as applied to specific players and, notably for this event, to the 'foreign-born' men playing for the Moroccan team. Though public debates often focus on evaluating the 'belonging' of individuals who are chosen for elite events to represent the nation, that lens did not seem to be applied to the Moroccan team. By exploring how diversity and diaspora were debated in relation to players for European teams in this same tournament, I explore here how the Moroccan example represents perhaps a new direction for diaspora: one which connects descendants across multiple nations and states without character judgments about who can belong.
\end{abstract}

\section{Keywords}

football - World Cup - Morocco - citizenship - belonging

\section{Résumé}

L'avenir de la diaspora est intimement lié à l'avenir de la diversité et aux différentes modalités que les États et nations peuvent mettre en place pour faire en sorte que leurs ressortissants mobiles et diverses soient acceptés et perçus comme appartenant au groupe. L'édition 2018 de la Coupe du monde de la FIFA, comme de nombreux événements sportifs internationaux, a cristallisé certains débats autour de la citoyenneté et l'appartenance au sujet de joueurs en particulier, et notamment au 
cours de cet événement, autour de joueurs "nés étrangers" jouant dans l' équipe marocaine. Si les débats publics se concentrent très souvent sur une évaluation du degrée "d' appartenance" des individus choisis pour participer à des événements d'élite pour représenter la nation, cette focale ne semblait pas s' appliquer à l'équipe marocaine. En explorant la manière dont la diversité et la diaspora étaient l' objet de débats comparé aux joueurs des équipes européennes dans la même compétition, j' aborde ici la manière dont l' exemple marocain représente sans doute une nouvelle voie pour la diaspora: l'interconnexion entre les descendants au travers de multiples pays et nations sans jugement quant à leur appartenance.

\section{Mots-clés}

football - Coupe du monde - Maroc - citoyenneté - appartenance

One of the surprising news stories about the 2018 World Cup, reported above (Figure 1) in the Washington Post, was the impressive number of 'foreign-born' players on the Moroccan team. 'Foreign-born' is a contentious notion in this context. It delineates a category of player that seems out of place on teams that are implicitly representing a national populous - especially given that citizenship is a requirement for each player representing 'their' nation. In some cases, like Switzerland, being 'foreign-born' indexes players who are naturalised citizens as a result of long-ago waves of migration (Berkowitz et al. 2018). Other teams noted for their 'diversity' - like France and Germany - do not rank highly in this list because almost all players, even the 'diverse' ones, were born in the countries they are representing. For Morocco, this enumeration reflects the inverse: the 17 'foreign-born' players on the 23-person team were products of previous generational waves of Moroccan migration. So, while born elsewhere, they were all citizens-by-birth of the Kingdom of Morocco. Playing for Morocco, then, becomes a kind of diasporic return. The visualisations of their trajectories provided by various media even resemble the diagrams sometimes used to depict flows of migration and diaspora (Figure 2).

In parallel, global sport competitions like the FIFA World Cup become a site where discourses about migration and diaspora appear. Such events promote collective sentiment and sense of unity that engenders nationalistic pride. They easily become both the projection of what a nation should be and a lightning rod for issues under the surface. The teams representing their 'nations' become 


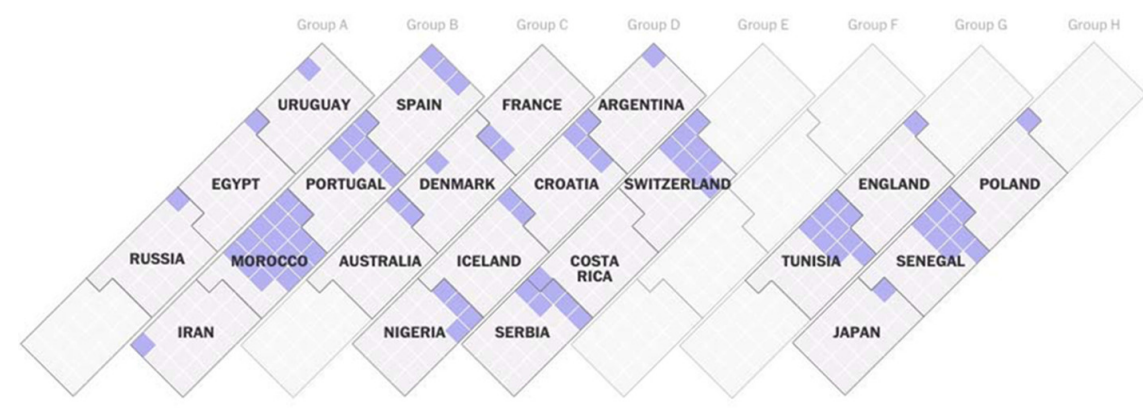

In fact, 22 of the

tournament's 32 teams have

at least one foreign-born

player. Morocco has 17.

FIGURE 1 Chart of foreign-born players in the 2018 World Cup

BERKOWITZ ET AL. 2018

a mirror for what is held within nation-state borders - for better or for worse. The coverage of the 2018 World Cup points as much to national pride as to the fallacy of methodological nationalism, in that most nations seem to be no longer (if they ever were?) made up of players born, raised and trained within their borders.

In that sense, the World Cup also becomes a lens for considering the future of diaspora. Diasporic diversity has often been framed - as in the text on "French Exports" in Figure 2 above - as a 'legacy of colonialism', and implicitly one that is located in 'destination countries' of the Global North. This form goes hand in hand with histories of inequality, stigmatisation, and continuing legacies of societal change in response to postcolonial mobilities. Less often, but equally as importantly, diaspora has been recognised as part of histories in the Global South, in which settler minorities have become distinctive and persisting communities (cf. Blunt 2005). I posit that the majority of 'foreignborn' players on the Moroccan team presents a notable, possibly novel, mode of diaspora in the South - not directly tied to colonialism or to similar unidirectional migration patterns, but fostered by multiple interlocking trajectories of migration that created multidirectional, complex, and diverse webs of diaspora.

Though Morocco has not been a powerhouse of diasporic engagement along the lines of some states, it does perpetuate a unique model of citizenship, passed exclusively and inalienably through ius sanguinis. Thus, over generations, Morocco exponentially increases its diasporic citizenry with every child born to a Moroccan citizen parent. As the inverse of the model of most liberal 
In total, 97 foreign-born players competed for the 32 countries (shown here) that qualified for the 2018 World Cup.

Foreign-born player's connection from birthplace to World Cup team

National team with

foreign-born players

National team with no foreign-born players

Between 1930 and 2018, 79 national teams have qualified for a World Cup tournament. Only eight have been champions.

$\begin{aligned} \text { Country } & \text { World Cup win } \\ \text { Country } & 7-14 \text { appearances } \\ \text { Country } & 6 \text { or fewer appearances }\end{aligned}$

\section{FRENCH EXPORTS}

Thirty-five French-born players competed for other countries, such as Senegal, Tunisia, and Morocco-a legacy of French colonialism in Africa and waves of immigration.

RILEY D. CHAMPINE, NGMSTAFF

RESEARCH: SCOTT ELDER

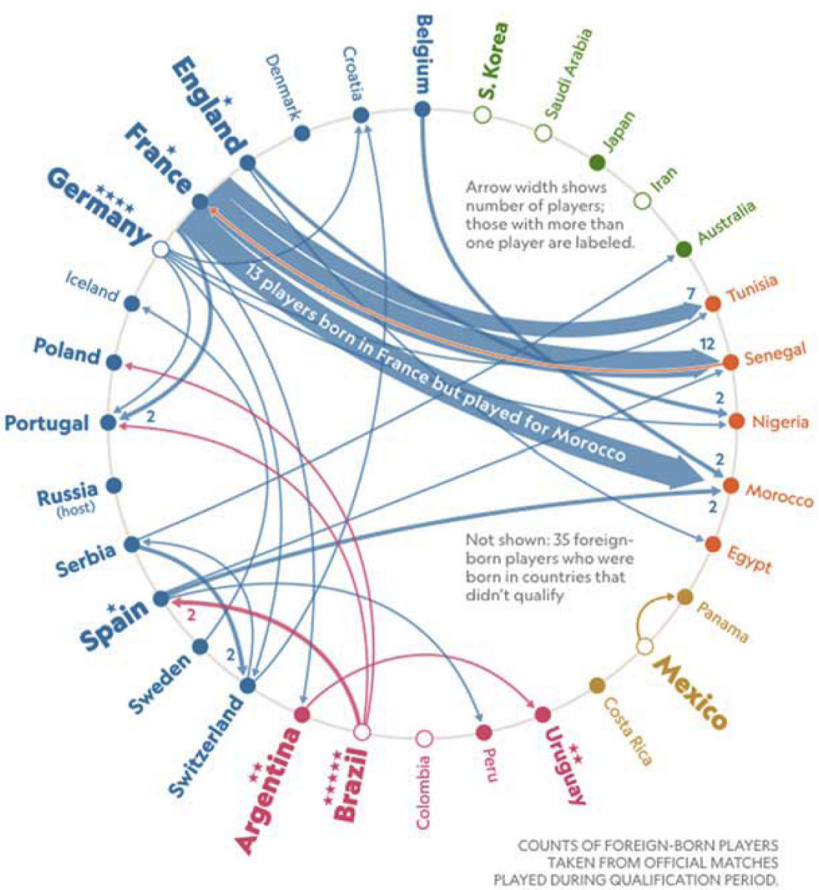

FIGURE 2 Chart of player origins and teams from the National Geographic CHAMPINE 2018

democracies, which allow paths to become and reject citizenship that usually require a demonstration of belonging in the nation, through a combination of loyalty, cultural integration, and presence (Aleinikoff and Klusmeyer 2001), this model may potentially create a new formulation of 'nation' by claiming all descendant Moroccans for Morocco, whether or not those citizens enact any connection to their ancestral homeland. Effectively, it generates an increasingly diverse global citizenry without making demands or setting parameters for what counts as 'belonging' in Morocco.

Comparing some discourses surrounding 'foreign-born' and diasporic players from European and Moroccan teams in the 2018 FIFA World Cup becomes a microcosm to explore the potential for flexibility of belonging in diaspora whether it is defined simply by descent or more complexly by characteristics of national belonging. I aim to open a discussion on the future of diaspora as being able to belong multiply - through multiple influences and in multiple directions - where the patrolling of characteristics that embody a 'nation' become less important than acceptance of individuals with complex trajectories across many homes. Public discourse about diasporic team members in and about Morocco becomes, perhaps, a model to follow for inclusivity of 
diversity, in contrast to simultaneously circulating discourses about European team members from migrant-origin backgrounds.

Yet, these discourses are tied to sports competition; perhaps unsurprisingly, they seem to shift depending on how well or poorly the teams fare, with belonging in the nation becoming to blame - or not - for their relative successes and failures. I delve below into some of the media discussions and circulations of the 2018 World cup which took into account configurations of diverse teams and how their formulations as diasporic were connected to their successes and challenges. First, I turn to the winning French team, held up as an example of 'beautiful diversity'; then, to some popular European players with familial backgrounds beyond Europe and how they respond to debates about their allegiances. Both of these present a different image than the Moroccan team, in how it was composed and how their performance (they did not make it past the first round) was interpreted inter- and intra-nationally. In taking the final example relative to the first two, I argue that the Moroccan team and its diasporic diversity shows the potential for different future conversations about diaspora and belonging.

\section{$2 \quad$ Playing Together}

France, the winning team of the 2018 global football tournament, reflects the more widely studied results of diaspora: an ideal of beautiful diversity (White 2018). In the inverse of the Moroccan side, here seventeen of the twenty-three players would be eligible to play for a different country, in one case by birth but mostly as children of parents who migrated. They reflect colonial and postcolonial mobilities that convene in contemporary France, along with inequalities and discrimination lingering around 'les immigrés'.

This team - and their win - have been held up as reflecting both the problems and the promises of France and the current politics of postcolonial diaspora. While some commentators see them as a sign of triumph for migrants everywhere, others contest framing the players through their backgrounds and characterise this club as a triumph of colorblind French republicanism (Beaman 2018). By playing together as French citizens, they "have the chance to act as a unifying force in country that continues to work through social issues" (White 2018, para. 12).

This is not the first time that France has been victorious with a 'diverse' team. Anthropologist Paul Silverstein (2018) recalls the discourses of emancipation that accompanied the 1998 World Cup win of the 'Black-Blanc-Beur' team, a similarly 'diverse' lineup. Yet, he argues, these discourses are also aligned with 
negative stereotypes of ethnicised working class masculinities, which are intertwined with the circumstances of state neglect that propel young disadvantaged men (of all varieties) towards football as path upwards. France's win thus reflects, in many respects, a perpetual postcolonial paradox: migration to the former colonial power enables some individuals to access opportunities, but only by (usually) labouring against discrimination and class inequalities first. Moreover, those emigrants and their descendants who succeed symbolise the exploitation of resources perpetrated by the colonial project and its continuing legacy.

France's $2018 \mathrm{~s}$ win creates some new openings into discourses of diasporic belonging. When host of The Daily Show Trevor Noah joked that "Africa won the World Cup" (Did Africa Just Win The World Cup? 2018), he received a personal letter from the French Ambassador to the United States emphasising the Frenchness of these players. Mr. Noah responded (Trevor Responds to Criticism from the French Ambassador - Between The Scenes 2018) that claiming them as African does not deny their Frenchness, but also includes them into 'his' Africanness (BBC News 2018) - a duality of belonging that seems, despite decades and generations of diasporic diversity, still difficult for many to reconcile. As Noah says, "Why can't they be both?"

In some ways, Noah's comment points to the particular controversies and political discourses that diaspora, as seen from the North, can and cannot make. While his claim that Africa won sparked significant discussion from many sides, the Financial Times headline "Morocco - A Team of Europeans" (Kuper 2018) did not garner a similar response, though it poses a parallel but inverted clash of identity between a national team and the bounty of a continent. These 'European' players in the Moroccan club have had access to elite training facilities and opportunities - reaped the benefits, in short, of the countries they call home, only to now contribute that benefit to their parental homeland. They are showing a kind of loyalty that might be called counter-diasporic: not just a remittance, but a 'return' that brings resources from abroad to foster homeland development (King and Christou 2009).

But this contribution to the homeland does not come up in such explicit terms as a motivation for joining the Atlas Lions. Kuper's reporting, as well as Tariq Panja's for the New York Times (2018), documents the problematic that confronted the Moroccans from Europe - all twenty of them, including those not 'foreign-born' but foreign-raised - when choosing to play on this team. Whether or not they have a real shot at playing for the team where they live, choosing to play for their ancestral home team is framed as an alternative or even problematic choice, not as a purposeful one or as an end goal in itself. The choice is complicated by allegiances in many directions, includ- 
ing pressure from family members, competition for places in their European countries, as well as the sense of bifurcated identity and their own sense of pride in being identified with one side or the other (Kuper 2019; Panja 2018).

Those who have made this choice are reported to enjoy the sense of playing together on a 'home' team, made up entirely of Moroccans (even if they come from many places). Despite language differences and cliques among those with common backgrounds, the team plays together. According to Dutch-Moroccan Sofyan Amrabat, "We're all Moroccans. We even all look the same" (Kuper 2018, para. 17). In this sense, they reflect a real diasporic diversity: a boomerang return to a place of ancestral origin, bringing along with them what they have become elsewhere. Recognising this diversity as equally 'beautiful' as the French squad would be the next step in recognising the brilliance of diaspora - as Trevor Noah said, of being both.

\section{$3 \quad$ Playing Sides}

Equally prominent news stories from this World Cup showed the darker side of national pride in diverse sports teams. Most widely covered was the story about German player of Turkish familial descent Mesut Özil, who, during a Turkish referendum vote and prior to the World Cup matches, posed for a photograph with Turkish president Recep Tayyip Erdoğan in May 2018. In light of Erdoğan's reputation for dictatorial conduct and human rights abuses, Özil's choice to pose with him was considered by some in the German public as showing the questionability of his 'German values'. After the World Cup tournament, Özil announced his resignation from the German national squad, tweeting (in English), "I am German when we win, an immigrant when we lose" (Bryant 2018, para. 5).

Özil's rhetoric of reversal in public opinion is not uncommon. In covering Özil's departure, The Guardian commentator John McManus (2018) cited similar stories of players from diverse backgrounds feeling valued and embraced when performing well and ethnically othered when not. Belgian player Romelu Lukaku, as one example, wrote: "When things were going well, I was reading newspapers articles and they were calling me Romelu Lukaku, the Belgian striker. When things weren't going well, they were calling me Romelu Lukaku, the Belgian striker of Congolese descent" (Lukaku 2018). Though Özil's othering was directly associated with a publicly diasporic act - posing with Erdoğan during a Turkish electoral referendum - some online comments and commentators color his departure as a coverup for his declining performance. 
These other versions of diasporic diversity call into question what was really 'beautiful' about the French team: their diversity, or the fact that they won? Would those players, especially those who can be portrayed as 'un-French', have been subject to the same rhetoric if they had lost? At some point it may come down to simply being accepted, unquestionably, as part of a community represented by the national team, rather than being valued instrumentally as a skilled player. As Moroccan player Nordin Amrabat put it, quoted in de Volkskrant: "If the coaches of the Dutch team want you because of your football skills, then know that there are 35 million Moroccans who want you as a human being" (Bahara 2018, para. 6; my translation). Thirteen members of the Moroccan squad are French citizens; effectively thirteen players who have the potential to be part of the 'beautiful diversity' are enacting that diversity in its inverse by playing for their ancestral homeland and, following Amrabat's logic, being more valued as a person than a player.

Yet, inevitably, no national discourse is universally welcoming. In January 2017, Moroccan radio personality Talal Chakir tweeted a hashtag \#NonAuBinationaux (no to bi-nationals) with reference to the newly forming Moroccan team. In contrast with the debates on belonging that emerged in European medias in the above examples, the response to Chakir was "attack on all sides", according to TelQuel magazine (Mohsine 2017), prompting him to delete the tweet. Though Chakir's retraction was quick - he was publicly rebuked by other journalists and the minister of Moroccans Abroad (Daoudi 2017) - it shows a parallel sentiment to other discourses of who may be allowed to belong in a national team. The difference here is an authoritative push for embracing the diaspora, recognisable even in the World Cup-themed songs released by many pop groups - both local and diasporic - promoting unity and pride in being Moroccan from anywhere. Within Morocco, negative sentiments are buried in the comments sections of football news items - in discussions of talented Moroccan born-and-raised players overlooked because of the Europeans filling the ranks, or debates over the 'Moroccanness' of imported players (Fangar 2018).

So what is new here? What signs from this World Cup might show the future of diaspora? I would argue that the 'newness' lies in this:

After scoring an own-goal in the final minutes of the Morocco-Iran game, effectively destroying Morocco's chances to advance past the first round, German-Moroccan player Aziz Bouhaddouz appeared on the Dutch small ads 
website Marktplaats as 'free for pickup' in Saint Petersburg. The site quickly removed the ad, but not before it circulated widely as a meme among Morocco fans in the Netherlands.

With the Netherlands not contending in the 2018 tournament, Dutch fans were split in their possible teams to show support. Many rooted for Belgium or Germany, while a substantial minority backed Morocco ("Dutch Football Fans Back Belgium, Germany and Morocco for the World Cup" 2018), reportedly because of the presence of Dutch-Moroccan players on the team ("World Cup 2018: Morocco Have Five Netherlands-Born Players in Their Squad" 2018). Yet, supporting Morocco meant not only the Dutch-Moroccan players, but all the players, from all backgrounds, and all Moroccan. It also meant eviscerating all the players, equally, when they make mistakes.

What is notable about the Bouhaddouz meme is that he is not advertised for pickup as a 'German' nor a 'Moroccan' player; he is simply a team player who made a fantastically bad error. Moreover, his error is a tragedy mourned by not only a national Moroccan public, but a diverse set of publics, irrespective of national and ethnic borders, as the meme circulates and is noted by a Dutch-based sports news site (see Figure 3) that is not exclusively for a DutchMoroccan public. In short, this response is a news item about the diaspora without being labeled as 'diasporic'.

His error was also diasporically defended, in a manner of speaking. A video circulated to my WhatsApp of a Dutch-speaking, possibly Moroccan-origin teenager, mourning the loss to Iran, but advising the audience to look at the bright side - Morocco scored a goal at the World Cup! Then dancing in celebration and dressing a cat in Moroccan team gear. Here, again, Bouhaddouz the 'German' is not the target; his specific diasporic trajectory becomes irrelevant. He is just a player on the Moroccan team, accessible to commentary by differently configured others who root for Morocco.

These orientations expand upon Trevor Noah's call to be able to "be both" because both designations of belonging - whether in Morocco or in Europe become somewhat irrelevant. Of course, the notability of the error, the conversation about it, and the pride or shame in the Moroccan 'goal' are all implicitly linked with a sense of Morocco as a homeland. Yet that characteristic is not a prerequisite for joining in the conversation. The diaspora references somewhere, but the rules about who can participate and belong are loosening. This diversity is not a postcolonial one, but a post-migration one that works multilaterally: 'Moroccanness' has seeped into other places and other places, carried by these diasporic players, have likewise enlarged the space that is Morocco. 


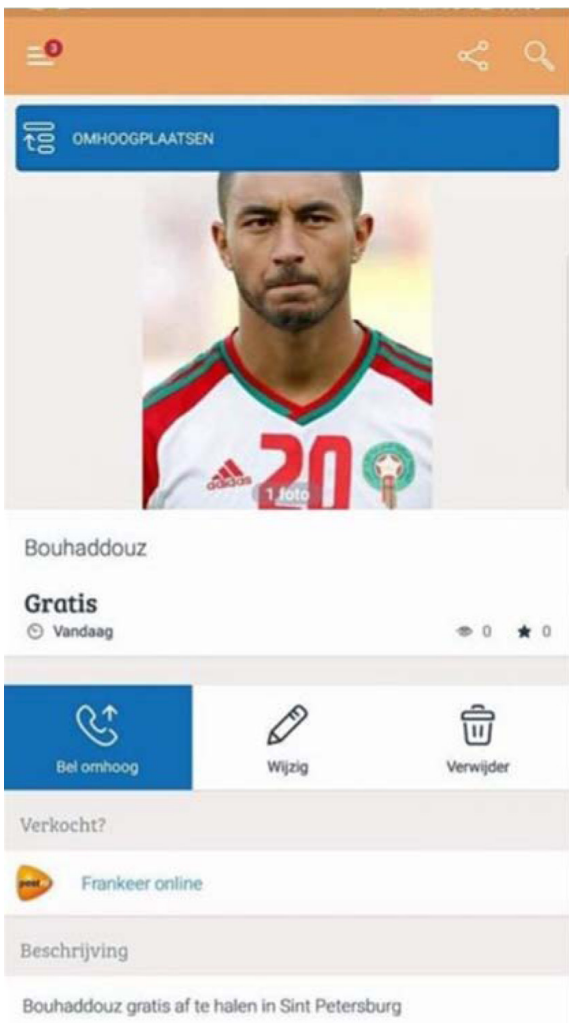

\section{FIGURE 3}

Advertisement for pickup: "Unlucky Bouhaddouz put up for sale on Marktplaats after his own-goal: 'Pickup in St Petersburg'” (original in Dutch: "Pechvogel Bouhaddouz na eigen goal aangeboden op Marktplaats: 'Afhalen in Sint-Petersburg'”, 2018)

The profound diversity of the Moroccan team initially caught my attention while watching the player presentation at the beginning of their first game. As the national anthem played and the camera panned down the line of players, only a minority of them seemed to be singing along. This is not necessarily surprising, given the complexity of the sociolinguistic landscape of diasporic Morocco (Wagner 2017). According to de Volkskrant, "[s] ome of them speak neither Arabic nor Berber. Some have only minor abilities in Berber. Ziyech, born and raised in a Berber home in Naarden, does his interviews with the Moroccan press in English" (Bahara 2018, para. 8; my translation). Players who grew up elsewhere may hardly be expected to know the Arabic words to the anthem as a language they may not speak. Furthermore, having lived and been trained for sport diasporically, the anthem would not necessarily have been drilled as part of their upbringing. This lack of national demonstrativeness did not rate commentary in the news. 
Such traditionally nationalistic markers of belonging being ignored perhaps shows new ways in which diaspora is complicating what it means to belong. Being able to speak the same 'national' language or being able to demonstrate allegiance through routinised performances like an anthem might elsewhere be fodder for controversy about allegiance to a nation. Unlike Özil, Lukaku, and others playing for European teams, these players are not being attacked for ambiguous membership. (At least, when they are attacked, the response is to mute the accusation rather than feed it.) It doesn't make a difference in how well they play - and that's what matters for representing the Kingdom of Morocco and getting to the World Cup.

In this sense, the example of the Moroccan team and the diasporically shared commiseration in their loss provides a more promising signal of a future for diaspora than the repetitive European debates about belonging. Naming the diversity of the French team as 'beautiful' backhandedly highlights the minefields of problems of social and ethnicised difference in France by emphasising the common citizenship that unites these 'diverse' individuals. The invisible diversity of the Moroccan team, instead, points towards a mode of inclusion that minimises difference by simply ignoring it. These players are all different, but all Moroccan. There is no need to attend to what might differentiate them. Perhaps this is what is intended by the French Republican mode of citizenship (Beaman 2018), but somehow gets lost in discourses of migration.

This reduction of the importance of migratory difference aligns in some ways with Trevor Noah's idea of 'being both'. The division of 'belonging' into one or the other category no longer seems to matter because the categories themselves become so complicated. Moroccans are in Morocco and in many other places; they are not 'both', they are multiple, because Morocco itself is becoming multiple through its many diasporic citizens. With the tenet of descent remaining firmly in place through Morocco's particular variety of inalienable citizenship, other elements of nationalism often used to define membership like language or moral values - seem to diminish in importance as Moroccans have a presence in places around the world. Moreover, though there remains a hard definition of Moroccanness as citizenship, it does not stop those who may affiliate with the Moroccan players - fans in the Netherlands, for example - from participating in 'being Moroccan' as they root for 'their' team.

In this sense, a looser version of diaspora, focusing on being multiple rather than being rooted, could work more productively towards creating diversity. Classic understandings of diaspora focus on the dynamics of belonging at a distance from a homeland that often serves as a defining presence. They illustrated how processes of inclusion and exclusion make room for an elsewhere in the here and now (Brah 1996; Cohen 1997). More often than not, these pro- 
cesses are codified as intrinsic to self through the symbols of national unity and identity. Yet, as this journal has shown over the past ten years, diaspora can often, in practice, be an instrumental resource as much as, or more than, a sense of belonging. As practicality is allowed to overturn the traditional tenets of national belonging, the defining traditions of diaspora as 'rootedness' can change shape. As states like Morocco put diasporic citizens of many generations to use for practical purposes, they simultaneously forge new openings in what it means to belong within the Moroccan diaspora. This focus may have its own negative effects - such as is rumored in this case, the superseding of diasporically-raised players over locally-raised ones - but it may also generate openings for diversities that enrich Morocco and the diasporic locations of its citizens. It's no wonder so many European Moroccans are choosing to play for their ancestral home. Even though Europe won, Morocco is putting together a beautiful team.

\section{References}

Aleinikoff, T. Alexander and Douglas Klusmeyer (Eds.). 2001. Citizenship today: global perspectives and practices. Washington, D.C.: Carnegie Endowment for International Peace.

Bahara, Hassan. 2018. 'Het Marokkaanse voetbalelftal; hoe de loyaliteit van de Leeuwen van de Atlas van twee kanten betwist wordt'. de Volkskrant. 8 June 2018. https://www .volkskrant.nl/gs-b97c83ba.

Beaman, Jean. 2018. 'Stop Calling the French World Cup Victory an "Immigrant Win"'. Washington Post. 20 July 2018. https://www.washingtonpost.com/news/made-by -history/wp/2018/o7/20/stop-calling-the-french-world-cup-victory-an-immigrantwin/.

Bв News. 2018. 'Noah Defends Africa World Cup Joke', 19 July 2018, sec. Africa. https:// www.bbc.com/news/world-africa-44885923.

Berkowitz, Bonnie, Chris Alcantara, Monica Ulmanu, and Chiqui Esteban. 2018. 'How Foreign-Born Players Put the "World" in World Cup'. Washington Post, 18 June 2018, sec. Sports - Analysis. https://www.washingtonpost.com/graphics/2018/sports/ world-cup-countries-of-birth/.

Blunt, Alison. 2005. Domicile and Diaspora:Anglo-Indian Women and the SpatialPolitics of Home. Oxford: Blackwell.

Brah, Avtar. 1996. Cartographies of Diaspora: Contesting Identities. London: Routledge. Bryant, Tom. 2018. 'Mesut Özil Walks Away from Germany Team Citing "Racism and Disrespect”'. The Guardian, 23 July 2018, sec. Football. https://www.theguardian.com/ football $/ 2018 / \mathrm{jul} / 22 /$ mesut-ozil-retires-german-national-team-discrimination. 
Champine, Riley D. 2018. 'See Which World Cup Teams Have the Most Foreign-Born Players'. National Geographic Magazine. July 2018. https://www.nationalgeographic .com/magazine/2018/o7/world-cup-fifa-soccer-players-national-teams-foreignborn/.

Cohen, Robin. 1997. Global Diasporas. London: UCL Press.

Daoudi, Hasna. 2017. 'Maroc-CAN 2017: Samira Sitail Mouche Un Chroniqueur Qui s' est Attaqué Aux Bi-Nationaux de l' équipe Nationale'. 22 January 2017. https://www .atlasinfo.fr/Maroc-CAN-2017-Samira-Sitail-mouche-un-chroniqueur-qui-s-estattaque-aux-bi-nationaux-de-l-equipe-nationale_a78886.html.

Did Africa Just Win The World Cup? 2018. The Daily Show With Trevor Noah. Comedy Central U k. https://www.youtube.com/watch?v=EJMG27YYAWU.

'Dutch Football Fans Back Belgium, Germany and Morocco for the World Cup'. 2018. DutchNews.Nl. 14June 2018. https://www.dutchnews.nl/news/2018/06/dutchfootball-fans-back-belgium-germany-and-morocco-for-the-world-cup/.

Fangar, Mohamed. 2018. 'تجديد دماء المنتخب ... إزاحة الستار مطلع شتنبر عن خيارات رونار.' Hespress. 8 August 2018. https://www.hespress.com/sport/401509.html.

King, Russell, and Anastasia Christou. 20o9. 'Cultural Geographies of Counter-Diasporic Migration: Perspectives from the Study of Second-Generation "returnees" to Greece'. Population, Space and Place 15 (2): 103-119. https://doi.org/10.1002/psp .543 .

Kuper, Simon. 2018. 'World Cup 2018: Morocco - a Team of Europeans'. Financial Times, 1 June 2018. https://www.ft.com/content/ec684d8o-6399-11e8-9oc2-9563ao613е56.

Lukaku, Romelu. 2018. 'I've Got Some Things to Say'. The Players' Tribune. 18 June 2018. https://www.theplayerstribune.com/en-us/articles/romelu-lukaku-ive-got-somethings-to-say.

McManus, John. 2018. 'It's Not Just Mesut Özil. All Diaspora Footballers Face the Same Conflict | John McManus'. The Guardian, 23 July 2018, sec. Opinion. https://www .theguardian.com/commentisfree/2018/jul/23/mesut-ozil-diaspora-footballersmigrant-players-arsenal-superstar-turkey-germany.

Mohsine, Réda. 2017. '\#NonAuxBiNationaux, le hashtag de la discorde'. Telquel.ma. 24January 2017. https://telquel.ma/2017/o1/24/nonauxbinationaux-le-hashtag-dela-discorde_1532681?fbrefresh=4.

Panja, Tariq. 2018. 'In Morocco, an Imported Team for the World Cup'. The New York Times, 17 September 2018, sec. Sports. https://www.nytimes.com/2018/o6/o5/sports/ world-cup-morocco.html.

'Pechvogel Bouhaddouz na eigen goal aangeboden op Marktplaats: "Afhalen in SintPetersburg"'. 2018. Sportnieuws. 15 June 2018. https://sportnieuws.nl/voetbal/ wk-2018/pechvogel-bouhaddouz-eigen-goal-aangeboden-op-marktplaats-afhalensint-petersburg/.

Silverstein, Paul. 2018. 'World Cup Summer in Postcolonial France'. Pluto Press (blog). 
3 July 2018. https://www.plutobooks.com/blog/world-cup-postcolonial-francefootball/.

Trevor Responds to Criticism from the French Ambassador - Between The Scenes. 2018. The Daily Show with Trevor Noah. Comedy Central U k. https://www.youtube.com/ watch?v=CODghcTpGWQ.

Wagner, Lauren B. 2017. Becoming Diasporically Moroccan: Linguistic and Embodied Practices for Negotiating Belonging. Clevedon: Multilingual Matters.

White, Adam. 2018. 'Liberté, Égalité, Diversity: How France Won the World Cup'. The Guardian, 17 July 2018, sec. Football. https://www.theguardian.com/football/2018/ jul/17/france-win-world-cup-didier-deschamps-diversity.

'World Cup 2018: Morocco Have Five Netherlands-Born Players in Their Squad'. 2018. ввС Sport. 12 June 2018. https://www.bbc.com/sport/football/44454330. 